$\xi=-1$

\title{
Revamping Technopreneurship Education in Public Higher University
}

\author{
Nor Haryanti, Md Nor1, Siti Maziah, Abdul Rahman1, Yusrina Hayati, Nik Muhammad Naziman1, Siti Norbaya, \\ Mohd Rashid1, Nadia Farleena, Mohd Aznan1
}

1Faculty of Business Management, Universiti Teknologi MARA Cawangan Kelantan, Kota Bharu City Campus, Jln. Sultan Ibrahim, 15050 Kota Bharu, Kelantan, Malaysia

\begin{abstract}
Envisioning new innovation strategy, it is wisely to fostering the technopreneurship area of education in public higher education. To be an entrpreneurial universities, it initiate to have a focus on undergraduate student starting from enrollment to graduation, which offered constant encouragement, training and support for their efforts to conceive and start up business enterprises with prototype they conceive. In this regards, this paper examines a factors required by the universities in bolstering the better prelude efforts towards the students in technopreneurship by indicating the competition, technology transfer and university policy. Sample of study was taken from undergraduate students at public university involving 146 students which already been taught the technopreneurship course at university. The descriptive statistics, multiple regression analysis and t-test were used to investigate the effect factors. In line with previous studies, the results reveal that competition, technology transfer and university policy statically significant in influencing the technopreneurship education at university. Surprisingly, the study shows that competition plays a crucial part in enhancing a better lookout in this innovation. The exposure from competition will drive them to be a creative person in nature and laterally develop an entrepreneurship skill in future. The result is useful for policy makers as well as university in considering the effect of these 3 factors in the eyes of undergraduates. Exploratory in nature, globalization and surge demand on technopreneurship thus evolve the trend in vibrant economic growth, industrialize and development context.
\end{abstract}

Keywords: Technopreneurship Education, Technology Transfer, Competition, University Policy

\section{Introduction}

"Serving a clearly heterogeneous population with seemingly homogenous interventions appears faulty and this reality needs to inform pro-entrepreneurship initiatives in future". [1]

Considering to broad literature, innovation and creativity via technopreneurship are the powerful drivers towards modern growth survival. Technopreneurship education provides much ongoing interpretation and responsiveness among universities since it's provides significant values of adventurous youth burning with energy, passion, creativity and intelligence. The creativity and innovation plays a crucial part in education process as it will precast the end result of developing the nations. Many universities have looked toward entrepreneurship technologies to assist them in making transition and obtain the flexibility necessary to educate well the undergraduates into the future [2] [3] [4] Selladurai( 2016) stress that Malaysia, Singapore, Korea, India, China particularly aims to exports more the industrial product based on tecnology by drawing policies match in encouraging start-ups, productivity, regulations, capital venture as well as promotion on education of technopreneurship.

Many public universities aiming for entrepreneurship education and research by evolving the transformation from tradisional university to more prudent and theoritically feasibility technological ideas and knowledge in generating properous venture. Initially theory on this relatively new phenomenon - technopreneurship, together with existing findings on technology transfer, competitions and university policy will be organized according to these three areas of technoprenuership research [5]. A unique theories conviction from [6] argues that a general positive attitude toward change orientation of entrepreneurship education. The weightage sought to entrepreneurship require more attention specifically public and private tertiary learning by implying more orientation based programme in order to produce well trained and ideas exploration graduates internationally [2] [7]. Understanding the level of succession of entrepreneurship intention among university students is particularly critical where the scourge of unemployment is profound [1]. Simply speaking, as a tool to override the hard times such as financial crisis, many observers believed this is the key implementation. Alive to this, government and higher education providers are investing in technopreneurship development, the gain of which remains to an ebbing of hope in the youth population.

Therefore, this study was conducted in order to explore the significant relationship via literatures upon 3 consequences technology transfer, competition and university policy to enhance creativity and innovation in technopreneurship education. 


\section{Historical Context of Technopreneurship Education}

An abundance theory emerged concerning technopreneurship in the context of education laterally start from case study made by [6] where the importance of consumer belief will result the attributions of repeating purchases. Shapero \& Sokol, (1982) come out with the independently model of [8] with the extinction of entrepreneurial event model (EEM) highlighting the foundation of feasibility, desirability and propensity to act towards entrepreneurship intention. Katz (2003) comeout with the chronology advancement between the enterpreneurship education and perceived to believe that the importance of added items in technology via enterprice education pursuasing a better engagement. Similar to this, more more research has very much revolved in the area of determinants, processes, outcome of technopreneurship education. Again,a review literature concerning determinants of technology transfer, competitions and university policy yet to be perceived [9] [10] [11]

\section{Technology Transfer}

Transfer of knowledge become due as it always is carried out to achieve the transfer objective. It believed to bring a major change in future result as long as person in charge to be tactical and supportive in bring down the knowledge skills. Apart from university based education plan competitions, there are private sector competitions sometimes driven by venture capitalists to garner interesting projects and also to screen prospective recruits for their funds The interactions among major stakeholders involved in knowledge creation and capitalization, universities, industries, government brings the optimization of commercialization of knowledge [12] Andrzej (2005) recognized knowledge and innovation as crucial factors from the top management. He argues that the technology transfer may transit the best value in it if all the academicians, policy makers, companies play their part effectively. It's a basic technical innovation that carries an after effect values in the forms of creativity and innovation dispersion. Amabile (2013) describes creativity as the ability to come with new ideas while Johnson (2001) considers technology captures any useful innovations. Following the preceding definitions, technology transfer can thus be defined as the ability to come with new ideas whose consequence is the development of useful innovations. Thus, technology transfer serves a functional purpose [13] that manifests through the idea-driven, business value generation from the exploitation of creative inventions or innovations in pursuit of solving business or societal problems. Pei, Noordin, Ting, \& Baharudin (2010) also focusing towards the failure factors of technoprenuership education and believed that technology impactful on internal and external basic of young techopreneur in gaining a branding product starts from the stages of education and it leads them to excell in the future.

\section{Competitions}

The best way in which entrepreneurship been encouraged is by business plan competition [12] and many more public and private universities had organised competition by giving out awards recognition. External factors associated with learning process technopreneurship within classes then being carried out in the form of competition- business entrepreneurship [14]. Malaysia specifically compressed the competition into 2 section namely academic and non-academic in order to nurture as well as promoting national technopreneurship initiatives [15]. The potential outcome resulting from this competition will then providing a new hybrid tool and a good signal towards potential seekers inventors. The teams receive air time with potential financiers, investors and mentors. However, the longer returns of this competition are yet to be discovered and need to observe. Oukil (2007) believed that the corporate structure via competition as in national innovation agenda will then create solving practical problems such as increasing productivity and encourage innovativeness, exploitation of new ideas and use of talents and competences. Entrepreneurship development will also help ideation and initiative to emerge and free economies from the drawbacks and constraints of the public sectors. Besides innovation and entrepreneurship development, recourse to knowledge will, of course, fasten the development process and up-grade capabilities in favor of a real and durable development. [16] [7] [2].

\section{University Policy}

The best solution in making one top edge technopreneurship education said that the participation and continuous commitment made by university itself. [17] Believed to be in order to transform Singapore's from investment driven economy into innovation driven economy, policy makers charted the needed of intellectual capital and its commercialization by creating value down from the university courses. The mode of entrepreneurial university mission and governance at a consequent level will then improve the rhythms of University in catering the needed of knowledge based economic growth [18] [19]. Sohn \& Kenney, 2007 argues that strong university-industry linkages are the key in fostering the techoprenuership as well as the strong commitment made by the government. The important contribution of universities to economic development is by focusing on entreprenurial focus on graduates. The famous metaphora quoted that university research was the magic seed that may grows the economic. This recognition perceived that the equally important roles play by the universities to realise all the planned setup by the government [16] Okorie, D.Y.Kwa, Olusunle, A.O.Akinyanmi, \& Momoh (2014) believed that in order to make it achievable, technopreneurship entails tertiary and professional development courses as well as strategic planning who will sharpen business skills and market savvy. To nurture the innovative culture at university, the technical session, workshops, conferences, seminar, training on the special fields need to handle.

In becoming Entrepreneurship University, modern teaching and training that match with the demand criterion as well as up to date syllabus curricular synonym at international standard being much concern. New entrepreneurs need to be educated and trained, particularly when it comes to exploitation of technologies and innovations [20] [3]. Selladurai, (2016) believed that many countries including Malaysia, the technopreneurship education still lacking and deserve an attention from government to be specific. Before, technopreneurship is not perceived as a formal educational outcome. The role of governments in supporting entrepreneurship development has to be firm so that the university policy can be conform. Morrison (2006) for example, cited a number of Arab countries whose governments have tried to promote entrepreneurship and succeeded to some extent. Arab countries have, in general, invested a lot in the information and communication technology (ICT) sector. This has helped organizations in the region to modernize their operations and up-grade their performance. Technological innovation-based entrepreneurship or 'technopreneurship' is very attractive because of its expected high impact compared to ordinary trade or service-based business. It is believed from the recent empirical studies show that the more innovative a start-up activity, the more its impact on growth [20]. 


\section{Data Methodology and Findings}

This study worked on case study survey method to gather a number of data from the undergraduates' students from Mara University of Technology Kelantan Branch in Malaysia. The gathered data were then being analyzed qualitatively and quantitatively using Statistical Package for the Social Science (SPSS) version $17 \mathrm{Re}-$ gression analysis. Later, the results are explained in details by using frequency distribution and reliability test supported with Pearson Correlation Analysis, Multicollinearity and Multiple Regression Analysis to test the relationship between dependant variable and independent variables [21] [22].The simple random sampling techniques were chosen as it encounters the requirements for this study [23] where $100 \%$ of them were undergraduates' students from Mara University of Technology Kelantan Branch from batch $2016-2017$. From the descriptive analysis $72 \%$ of them are female and $28 \%$ of them are male ages from 21 and $23.100 \%$ of them are from Bachelor Degree of Statistic part 5 and 6 in July 2017.In order to examine the result, we follow the methodology of recent literature, focusing on the enhancing factors in technoprenuership education to higher public universities [12] [24] using the descriptive analysis, correlation and multiple regression analysis. To reliability test, it shows Cronbach's Alpha for Technoprenueship education (dependent variable) is 0.874 . It indicates that the internal consistency is good and the questions developed are reliable. The Cronbach's Alpha for technology transfer, competitions and university policy were $0.901,0.857$ and 0.783 respectively, thus the construct measures are deemed reliable and all items in the construct measures are retained We assumed the function as;

$\begin{array}{ll}\mathrm{ENT}=\alpha+\beta_{1} \mathrm{TT}+\beta_{2} \mathrm{CO}+\beta_{3} \mathrm{UP}+\mathrm{e} \quad \text { (Equation 1) } \\ \text { Where; } & \\ \text { ENT } & \text {-technopreneurship education } \\ \text { TT } & \text {-technology transfer } \\ \mathrm{CO} & \text {-competition } \\ \mathrm{UP} & \text {-University Policy } \\ \mathrm{e} & \text {-errors }\end{array}$

Convert to the values:

$\mathrm{ENT}=1.181+0.244 \mathrm{TT}+0.394 \mathrm{CO} 0.111 \mathrm{UP}+\mathrm{e}$ (Equation 2)

The coefficient value for competition is the highest among other variables and it shows that this variable is the most factors that influence the succession of technopreneurship education in public university. Whereby the others 2 factors university policy and technology transfer indicate for $1 \%$ increase of these variables, technopreneurship education will increase by 0.2444 and 0.111 respectively.

Table 1: Variables Correlations in technopreneurship education in 20162017

\begin{tabular}{|c|c|c|c|c|c|}
\hline & & ENT & TT & CO & UP \\
\hline ENT & $\begin{array}{c}\text { Pearson Correla- } \\
\text { tion }\end{array}$ & 1 & $.759^{* *}$ & $.875^{* *}$ & $.626^{* *}$ \\
\hline & Sig. (2-tailed) & & .000 & .000 & .000 \\
\hline & $\mathrm{N}$ & 146 & 146 & 146 & 146 \\
\hline
\end{tabular}

**. Correlation is significant at the 0.01 level (2-tailed).

The data provided in Table 1 shows that the correlation between all variables have a positive relationship at $99 \%$ significant level. It shows that the relationship between technopreneurship education with the technology transfer, competition and university policy is positive and significant at 0.01 level of significant.

Table 2: Statistic summary for technopreneurship education

\begin{tabular}{|c|c|c|}
\hline $\mathbf{R}$ & $\mathbf{. 7 1 9}^{\mathbf{a}}$ & \\
\hline R Square & $\mathbf{. 6 1 8}$ & \\
\hline $\mathbf{F}$ & $\mathbf{2 5 . 3 6 0}$ & Sig. $\mathbf{0 0 0}^{\mathbf{a}}$ \\
\hline \multicolumn{3}{|c|}{$\mathbf{~}$} \\
\hline \multicolumn{3}{|c|}{ Sig. } \\
\hline (Constant) & 2.922 & .004 \\
\hline
\end{tabular}

\begin{tabular}{|c|c|c|}
\hline TT & 2.555 & .012 \\
\hline CO & 2.658 & .009 \\
\hline UP & 2.004 & .018 \\
\hline
\end{tabular}

a. Dependent Variable: Technopreneurship Education

In answering the objectives of the study, Table 2 above shows the value of $\mathrm{R}$ obtained is $71.9 \%$ and the $\mathrm{R}$ Square or coefficient of determination of 0.618 . It means that only $61.8 \%$ of the variation in ENT is explained by changes in TT, CO and UP variables. The p-value for the F-test statistics is 0.000 which is less than 0.05 significance level. Therefore, it is significant and the null hypotheses are rejected. It means that at least one of the independent variables is useful in order to predict the dependent variable. The overall regression model is reliable since the research show significant value which is 0.00 or $100 \%$. Meanwhile in considerable to coefficient t-statistic for all the variables, the T-statistic value for all variables are more than $t$-critical value, the decision is reject null hypothesis because there is a relationship between technology transfer, competitions and university policy with technopreneurship education in public university. It is tandem to the overall objectives supported by [4] [11] [16] [25] in laterally confessed to believed that these 3 variables play an important factor in revamping the succession technopreneurship model in higher public education.

\section{Conclusion}

To this end of the study executed from a positive standpoint surveyed 146 students in derived hyhothesis relationship. Finding believed that competitions plays an abundant factor in excelling the technopreneurship among undergarduates students [18] [19]. Even so, technology transfer and university policy also plays as much needed factors with aiming of sound model for revamping the techopreneurship education [10] [25] [3]. Forum (2009) had urged the innovation to the top of the development agenda by providing policy underpinning of technopreneurship education theory at the university. It is essential for policy makers, universities as well as researchers to recognize the technopreneurship pattern [12] [24]. It is necessities to develop a firm creativity and innovation process in technopreneurship aiming for new scientist and inventor who technologically capable, productivity driven and competitive at both the local and global markets. In order to be sustained and embrace the economy, the local market pursues young inventors in growth continuation [17] [18] [2]. The pedagogy mainstream of creativity and innovation must in line with the government objective in enable environment for this to thrive. Entrepreneurs are basically creative and innovative. Creativity and innovation are the distinguishing marks of the entrepreneur. Two dimension of creativity and innovation sparks an eye opener in different ways and recognise the resources available as to create their own prototype [26] [24] [5]. A tiny and a silly idea would work the best in vibe of technopreneurship and thus the commitment from all the angle agencies much more needed. The process to seeing something through to the end and not being satisfied until all is accomplished is a central motivation for entrepreneurs. Thus, believe it or not, the technopreneurship education requires greatest attention.

Serving a clearly heterogeneous population with seemingly homogenous interventions appears faulty and this reality needs to inform pro-entrepreneurship initiatives in future.

\section{Acknowledgement}

The authors would like to express their appreciation to the Institute of Research Management \& Innovation of MARA University of Technology (UiTM) Academic \& Research Assimilation (ARAS) 2016-2018 for funding the research. 


\section{References}

[1] C. Eresia-Eke and S. d. V. \&. P. Jean-Claude, "Study Streams and Student Entrepreneurial Intention," Acta Universitatis Danubius. Economica, no. 5, pp. 251-265, 2016.

[2] M. Selladurai, "Conceptual Framework On Technoprenuership," SELF Journal Of Social Science , pp. 92-97, 2016.

[3] J. Morrison, International business environment: Global and local marketplaces in a changing world., New York: Palgrave MacMillan, 2006.

[4] T. M. Amabile, Componential Theory of Creativity, Sage Publications, 2013.

[5] H. B. Singhry, "Precursor of technology entrepreneurship: A structured literature review," Nigerian Journal of Management Technology \& Development, 3(2), p. 89-98, 2012.

[6] Ajzen, Icek and M. Fishbein, Understanding Attituted and Predeicting Social Behaviour, Englewood Cliffs: Prentice Hall, 1980.

[7] M.-S. Oukil, The Development of Entrepreneurship in the Middle East and North Africa: An Overview of Constraints and Perspectives, Business Excellence and Competitiveness in the Middle East and North Africa, Editor, Allam, 2007.

[9] G. Solomon, S. Duffy and A. Tarabishy, "The state of entrepreneurship education in the United States: A nationwide survey and analysis.," International Journal of Entrepreneurship Education,, pp. 65 86, 2002.

[10] D. F. Kuratko, "ENTREPRENEURSHIP EDUCATION IN THE 21ST CENTURY:FROM LEGITIMIZATION TO LEADERSHIP," in USASBE National Conference, 2004.

[11] J. A. Katz, "The chronology and intellectual trajectory of American entrepreneurship education: 1876-1999," Journal of Business Venturing Volume 18, Issue 2, p. 283-300, 2003.

[12] H. Etzkowitz, A Triple Helix of university-industry-government interactions, New York \& London: Routledge Taylor \& Francis Group, 2008.

[13] A. J. Cropley and D. H. \& Cropley, Fostering creativity: A diagnostic approach for education and organizations, Cresskill, NJ : Hampton Press , 2009

[14] D. S. Siegel, P. Westhead and M. Wright, "Science Parks and the Performance of New Technology-Based Firms: A Review of Recent U.K. Evidence and an Agenda for Future Research," Business Economics , p. 177, 2003.

[15] W. E. Forum, "Educating the Next Wave of Entrepreneurship:Unlocking entrepreneurial capabilities to meet the global challenges of the 21 st century," 2009

[16] A. S. Miner, V. D, E. M and T. Rura, The Magic beanstalk Vision of Universities Venture formation. The entreprenuership dynamic Stanford CA: Stanford University Press, 2000.

[17] P. K. Wong, Y. P. Ho and A. Singh, "Towards an "Entrepreneurial University" Model to Support Knowledge-Based Economic Development: The Case of the National University of Singapore," Elsevier World Development Vol. 35, No. 6, p. 941-958, 2007.

[18] P. K. Wong and Z. L. He, "A comparative study of innovation behavior in Singapore's KIBS and manufacturing firms.," Service Industries Journal, 25(1), pp. 21-42, 2005.

[19] D. W. Sohn and M. Kenney, "Universities, Clusters, and Innovation Systems:The Case of Seoul, Korea," Elsevier World Development Vol. 35, No. 6, p. 991-1004, 2007.

[20] P. Mueller, "Exploiting entrepreneurial opportunities: The impact of entrepreneurship on growth," Small Business Economics, 28(4), p. 355-362, 2007.

[21] N. K. Malhotra, Marketing Research; an Applied Orientation 6th Edition, USA: pearson Education. , 2010.

[22] M. Saunders and P. \&. T. A. Lewis, reserach methods for business Studnts 4th Edition, Harlow England: Prentice Hall, 2009.

[23] S. M, L. P and T. A, Reserach Methods for business students (4th Edition), Harlow, England: Prentice Hall, 2009.

[24] D. Johnson, "What is innovation and entrepreneurship? Lessons for larger organisations," Industrial and Commercial Training, Vol. 33 Iss 4, pp. 135 - 140, 2001.

[25] N. Okorie, D.Y.Kwa, S. Olusunle, A.O.Akinyanmi and I. Momoh, "Technoprenuership:An Urgent Need In The Material World For Sustainable In Nigeria," European Scientific Journal October 2014 Vols. vol.10, No.30, pp. 59-73, 2014

[26] W. L. Tan, K. Egge and O. Mohamed, "National Venture Competition and Technopreneurship Development in Malaysia," Journal for International Business and Entrepreneurship. 11, (2), pp. 69-81, 2010

[27] Ajden, Icek and M. Fishbein, Understanding Attitutes and Predict- ing Social Behaviour, Englewood Cliffts: Prentice Hall, 1980.

[28] A. Shapero and L. Sokol, The social dimensions of entrepreneurship. In The Encyclopedia of entrepreneurship, Englewood Cliffs, NJ: Prentice Hall., 1982.

[29] L. K. Pei, K. A. Noordin, Y. P. Ting and A. S. Baharudin, "Failure factors of The Malaysian IT technopreneurship," in International Conference on Science and Social Research, Kuala Lumpur, 2010. 